\title{
PENGGUNAAN MEDIA KARTU BERGAMBAR DALAM KETERAMPILAN MENULIS KARANGAN SEDERHANA BAHASA JERMAN SISWA KELAS XI IPS SMA NEGERI 1 SEGERI KABUPATEN PANGKEP
}

\author{
Miftahul Jannah ${ }^{1}$ dan Hasmawati ${ }^{2}$ \\ Fakultas Bahasa dan Sastra, Universitas Negeri Makassar \\ Email ${ }^{1}:$ miftahu193@gmail.com
}

\begin{abstract}
ABSTRAK
Tujuan penelitian ini adalah untuk mendapatkan data tentang efektivitas media kartu bergambar dalam keterampilan menulis karangan sederhana bahasa Jerman siswa kelas XI IPS SMA Negeri 1 Segeri. Penelitian ini bersifat eksperimen yang mengumpulkan datanya melalui tes menulis. Adapun data penelitian ini dianalisis dengan analisis statistik inferensial uji-t. Populasi penelitian ini adalah siswa kelas XI IPS SMA Negeri 1 Segeri yang terdiri atas 4 kelas. Sampel yang digunakan sampel acak (Random Sampling). Jumlah sampel adalah 2 kelas yakni kelas XI IPS 1 sebagai kelas eksperimen yang terdiri dari 20 siswa dan kelas XI IPS 4 sebagai kelas kontrol yang teridir dari 20 siswa. Hasil analisis data menunjukkan $\mathrm{t}$ hitung $2,98>\mathrm{t}$ table 2,03 pada taraf signifikan 0,05. Hasil penelitian menunjukkan bahwa penggunaan media kartu bergambar efektif dalam keterampilan menulis karangan sederhana bahasa Jerman siswa kelas XI IPS SMA Negeri 1 Segeri.
\end{abstract}

Kata Kunci: Media Kartu Bergambar, Keterampilan Menulis, Bahasa Jerman

\begin{abstract}
The purpose of this study was to obtain data on the effectiveness of picture card media in a simple essay writing skill by using German language class XI IPS SMAN 1 Segeri . This study is an experiment that collected data through the writing test. The data were analyzed by inferential statistical analysis t-test. The study population was class XI IPS 1 which consisted of four classes. Samples which was used a random sample. The number of samples was 2 classes namely class XI IPS 1 as an experimental class which consisted of 20 students and class XI IPS 4 as the control class consisted of 20 students. The results of the data analysis showed 2,98 $\mathrm{t}$ value $>\mathrm{t}$ table 2.03 at the 0.05 significance level. The results showed that the use of a picture card media effectively in a german language simple essay writing skills of students class XI IPS SMAN 1 Segeri.
\end{abstract}

\section{Keywords: Picture Card Media, Writing Skills, German Language}

\section{PENDAHULUAN}

Bahasa berperan penting

dalam berkomunikasi. Salah satu fungsi bahasa adalah sebagai alat komunikasi yang digunakan manusia dalam kehidupan sehari-hari. Melalui bahasa, seseorang dapat menyampaikan ide, pikiran, gagasan ataupun informasi kepada orang baik secara lisan maupun tertulis. Semakin tinggi penguasaan bahasa seseorang, 
semakin baik pula penggunaan bahasanya dalam berkomunikasi, maka akan terjalin pula interaksi sosial yang baik antar manusia. Mengingat pentingnya bahasa sebagai alat komunikasi, maka di berbagai lembaga pendidikan di Indonesia telah diajarkan berbagai bahasa mulai dari bahasa daerah, bahasa Indonesia sebagai bahasa nasional sampai pada bahasa asing. Salah satu bahasa asing yang telah diajarkan di Sekolah Menengah Atas (SMA) yaitu bahasa Jerman.

Pada pembelajaran bahasa Jerman, ada empat aspek kompetensi berbahasa yang perlu dikuasai dan dikembangkan, yaitu kemampuan menyimak, kemampuan membaca, keterampilan berbicara, dan keterampilan menulis. Keempat aspek kompetensi berbahasa tersebut ditunjang oleh dua aspek kemampuan yaitu tata bahasa dan kosakata. Keempat kompetensi berbahasa tersebut saling berkaitan satu sama lain. Dari keempat keterampilan tersebut dipilih keterampilan menulis sebagai acuan penelitian. Pembelajaran menulis terkadang terhambat karena kurangnya kemampuan siswa dalam menyampaikan ide atau gagasan. Terlebih lagi tidak didukung oleh latihan-latihan untuk menulis. Kesulitan ini terjadi selain karena halhal tersebut di atas dapat juga disebabkan karena proses pembelajaran yang terkadang membuat siswa merasa bosan. Oleh karena itu, seorang guru harus memiliki inovasi baru dalam proses pembelajaran, sehingga dapat meningkatkan minat siswa untuk belajar.

Berdasarkan hasil observasi yang dilakukan di SMA Negeri 1 Segeri Kabupaten Pangkep diperoleh data bahwa rata-rata siswa masih mengalami kesulitan dalam menulis karangan sederhana bahasa Jerman. Oleh karena itu, peneliti melakukan penelitian dengan menggunakan media kartu bergambar dalam keterampilan menulis karangan sederhana bahasa Jerman. Media kartu bergambar merupakan media gambar yang berbentuk kartu yang berisi gambar dan kosakata sehingga dapat memudahkan siswa dalam merangkai kata menjadi kalimat sehingga menjadi sebuah karangan.

Berdasarkan uraian diatas, maka peneliti melakukan suatu penelitian dengan judul "Penggunaan Media Kartu Bergambar dalam Keterampilan Menulis Karangan Sederhana Bahasa Jerman Siswa Kelas XI IS SMA Negeri 1 Segeri Kabupaten Pangkep"

\section{MEDIA PEMBELAJARAN}

Media pembelajaran merupakan wahana penyalur atau wadah pesan pembelajar. Media pembelajaran mempunyai peranan penting dalam proses pembelajaran yaitu untuk menarik perhatian siswa dan sebagai alat yang dapat menyampaikan pesan dari setiap mata pelajaran. Dengan menggunakan media yang kreatif, inovatif, dan variatif, para guru dapat menciptakan suasana belajar yang menarik bagi 
siswa. Musfiqon (2012: 28) mendefinisikan bahwa media pembelajaran sebagai alat bantu berupa fisik maupun nonfisik yang sengaja digunakan sebagai perantara antara guru dan siswa dalam memahami materi pembelajaran agar lebih efektif dan efisien.

Fungsi media pembelajaran adalah sebagai alat bantu siswa dalam proses pembelajaran yaitu berupa media dan sarana untuk membantu siswa agar lebih tertarik sehingga dapat membangkitkan motivasi dan rangsangan belajar pada siswa.

\section{MEDIA KARTU BERGAMBAR}

Media kartu bergambar termasuk ke dalam media grafis. Media grafis disebut juga media dua dimensi yaitu media yang mempunyai ukuran panjang dan lebar. Media ini seperti gambar, foto, grafik, bagan atau diagram, poster, kartun, komik, dan lain-lain.

Media kartu bergambar atau flashcard merupakan media kartu yang berisi gambar, di mana gambarnya dapat berasal dari buatan sendiri atau gambar/foto yang sudah ada dan digunakan untuk memudahkan siswa saat proses belajar.

Susilana dan Riyana (2009: 96) mengemukakan bahwa cara penggunaan media kartu bergambar yaitu:

1. Kartu-kartu yang sudah disusun dipegang setinggi dada dan menghadap ke depan siswa.
2. Cabutlah satu persatu kartu tersebut setelah guru selesai menerangkan.

3. Berikan kartu-kartu yang telah diterangkan tersebut kepada siswa yang duduk di dekat guru. Mintalah siswa untuk mengamati kartu tersebut satu persatu, lalu teruskan kepada siswa yang lain sampai semua siswa kebagian.

Setiap media pembelajaran memiliki kelebihan dan kekurangan. Begitu pula deengan media kartu bergambar. Ada beberapa kelebihan dan kekurangan yang akan diperoleh dari sebuah kartu bergambar.

Susilana dan Riyana (2009: 95) menjelaskan kelebihan media kartu bergambar sebagai berikut:

1. Mudah untuk dibawa-bawa: ukuran yang kecil membuat kartu ini dapat disimpan di dalam tas atau di saku, sehingga dapat digunakan dimana saja.

2. Praktis: Cara pembuatan dan penggunaannya yang mudah serta tidak membutuhkan listrik, menjadikan media ini sangat praktis saat akan digunakan.

3. Gampang diingat: Media ini menyajikan pesan-pesan pendek yang dapat memudahkan siswa untuk mengingat pesan-pesan yang disampaikan dalam proses pembelajaran.

4. Menyenangkan: Penggunaan media ini dapat melalui permainan sehingga proses pembelajaran akan lebih menyenangkan bagi siswa. 
Sedangkan kekurangan dari media kartu bergambar adalah hanya menggunakan persepsi indera mana saja dan ukurannya sangat terbatas untuk kelompok besar.

\section{METODE PENELITIAN}

Penelitian ini adalah penelitian yang menggunakan dua variabel, yaitu variabel bebas dan variabel terikat. Penggunaan media kartu bergambar sebagai variabel bebas $(\mathrm{X})$, sedangkan keterampilan menulis siswa sebagai variabel terikat (Y).

Penelitian ini adalah penelitian

True Eksperimental dengan bentuk Pre-test Post-test Control Group. Melibatkan dua kelompok yaitu kelas eksperimen yang menggunakan media kartu bergambar dan kelas kontrol yang tidak menggunakan media kartu bergambar dalam keterampilan menulis karangan sederhana bahasa Jerman.

Penilaian keterampilan menulis yang digunakan merujuk pada kriteria penilaian Bolton. Sedangkan untuk populasi dan sampel dalam penelitian ini adalah siswa Kelas XI IPS SMA Negeri 1 Segeri Kabupaten Pangkep. Dimana kelas XI IPS 1 sebagai kelas eksperimen yang terdiri dari 20 siswa dan kelas XI IPS 4 sebagai kelas kontrol yang terdiri dari 20 siswa.

Dalam penelitian ini teknik analisis data yang digunakan adalah teknik analisis inferensial yang terdiri dari uji normalitas dengan rumus chikuadrat, uji homogenitas, dan uji-t untuk hipotesis.

\section{PEMBAHASAN}

Pada pelaksanaan penelitian ini, pembelajaran dilakukan selama empat kali. Pada kelas eksperimen siswa diajar dengan menggunakan media kartu bergambar dalam keterampilan menulis karangan sederhana bahasa Jerman, sementara kelas kontrol diajar dengan tidak menggunakan media kartu bergambar.

Hasil pre-test menunjukkan bahwa nilai rata-rata (mean) untuk kelas eksperimen adalah 30,6 dan kelas kontrol adalah 28,35 dalam keterampilan menulis karangan sederhana bahasa Jerman siswa kelas XI IPS SMA Negeri 1 Segeri kabupaten Pangkep, dimana jumlah skor perolehan untuk kelas eksperimen 618 dan kelas kontrol adalah 542. Uji normalitas pada data pre-test pada kedua kelas menunjukkan bahwa kelas eskperimen dan kontrol memiliki chikuadrat hitung masing-masing lebih kecil dari chi-kuadrat tabel, $\chi_{\text {hitung }}<$ $\chi_{\text {tabel }}$, dmana pre-test kelas eskperimen $(-24,02<9,49)$ dan pretest kelas kontrol $(-49,14<9,49)$, sehingga distribusi data pre-test dinyatakan normal.

Berdasarkan hasil post-test, penggunaan media kartu bergambar berdampak positif pada peningkatan keterampilan menulis karangan sederhana siswa. Hal itu bisa dilihat dari perolehan nilai post-test siswa, dimana pada kelas eksperimen nilai terendah yaitu 29 dan nilai tertinggi 71 dengan nilai rata-rata 44,25 , 
sedangkan pada kelas kontrol diperoleh nilai 14 untuk nilai terendah dan 57 untuk nilai tertinggi dengan nilai rata-rata 33,3.

Selanjutnya, dianalisis dengan uji$\mathrm{t}$ untuk melihat hasil akhir penelitian ini, masing-masing kelas dengan rumus yang sama. Hasilnya adalah $t_{\text {hitung }}$ kelas eksperimen $=2,98$ sementara $t_{\text {tabel }}=2,03$, jadi $t_{\text {hitung }}$ $>t_{\text {tabel }}(2,98>2.03)$. Dengan demikian, $\mathrm{H}_{1}$ yang menyatakan bahwa penggunaan media kartu bergambar efektif dalam keterampilan menulis karangan sederhana bahasa Jerman siswa kelas XI IPS SMA Negeri 1 Segeri kabupaten Pangkep diterima dan $\mathrm{H}_{0}$ yang menyatakan bahwa penggunaan media kartu bergambar tidak efektif dalam keterampilan menulis karangan sederhana bahasa Jerman siswa kelas XI IPS SMA Negeri 1 Segeri kabupaten Pangkep dinyatakan ditolak. Sehingga dapat disimpulkan bahwa, karena $\mathrm{H}_{1}$ diterima maka penelitian tentang penggunaan media kartu bergambar dalam keterampilan menulis karangan sederhana bahasa Jerman siswa kelas XI IPS SMA Negeri 1 Segeri kabupaten Pangkep, dinyatakan berhasil.

\section{KESIMPULAN}

Kesimpulan dari hasil penelitian ini adalah:

1. Untuk kelas eksperimen nilai yang diperoleh dari hasil post-test rata-rata (mean) dari 20 siswa adalah 44,25 dengan nilai tertinggi adalah 71 dan terendah adalah 29. Terdapat 6 siswa yang memeroleh nilai pada kelas interval 29-37, 9 siswa memperoleh nilai pada kelas interval 38-46, 0 siswa memperoleh nilai pada kelas interval 47-55, 4 siswa memperoleh nilai pada kelas interval 56-64, dan 1 siswa memperoleh nilai pada kelas interval 65-73.

2. Untuk kelas kontrol nilai yang diperoleh dari hasil post-test ratarata (mean) dari 20 siswa adalah 33,3 dengan nilai tertinggi adalah 57 dan terendah adalah 14. Terdapat 3 siswa memperoleh nilai pada kelas interval 14-22, 10 siswa memperoleh nilai pada kelas 23-31, 0 siswa memperoleh nilai pada kelas interval 32-40, 4 siswa memperoleh nilai pada kelas interval 41-49, dan 3 siswa memperoleh nilai pada kelas interval 50-58.

3. Dari hasil analisis data uji-t yang telah dilakukan dengan nilai posttest sebanyak 40 siswa diperoleh data yaitu $t_{\text {hitung }}>t_{\text {tabel }}$ dimana $t_{h}=$ $2,98>t_{t}=2,03$ pada taraf signifikan 0,05 yang berarti jika $t_{\text {hitung }}>\mathrm{t}_{\text {tabel }}$ maka terima $\mathrm{H}_{1}$ dan tolak $\mathrm{H}_{0}$. Dimana $\mathrm{H}_{1}$ yang berbunyi bahwa media kartu bergambar efektif dalam keterampilan menulis karangan sederhana bahasa Jerman siswa kelas XI IPS SMA Negeri 1 Segeri kabupaten Pangkep.

\section{DAFTAR PUSTAKA}

Finoza, L. 2006. Komposisi Bahasa Indonesia untuk Mahasiswa 
Non Jurusan Bahasa. Jakarta:

Diksi Insan Mulia.

Gie, T.L. 2002. Terampil Mengarang.

Yogyakarta: Andi.

Jauhari, Heri. 2013. Terampil Mengarang. Bandung: Nuansa Cendekia.

Musfiqon, HM. 2012. Pengembangan Media dan Sumber Pembelajaran. Jakarta: PT. Prestasi Pustakaraya.

Resmini, Novi, dkk. 2009. Kebahasaan (Ponologi, Morfologi, Semantik). Bandung: UPI Press.

Semi, M. Atar. 2007. DasarDasarKeterampilanMenulis. Bandung: Angkasa.

Suhadi. 2007. Memenangkan Lomba Mengarang. Jakarta: Balai Pustaka.

Susila, Rudi dan Cepi Riyana. 2009. Media Pembelajaran. Bandung: CV. Wacana Prima. 